\title{
Mapping War Geoheritage: Recognising Geomorphological Traces of War
}

https://doi.org/10.1515/geo-2018-0030

Received March 2, 2018; accepted July 24, 2018

\begin{abstract}
In the topography of war landscapes the remains of war are found in the form of trenches, bombing craters and remnants of war infrastructure. Today war landscapes are "overlaid" by post-war "layers" of cultural landscapes. It requires non-invasive remote-sensing methods, e.g. time series of aerial photographs and high-resolution terrain models (LiDAR digital terrain model) to recognize these landscapes.

In the study area on Kras Plateau (SW Slovenia) over one hundred kilometres of World War I trenches are preserved in the NW part of the plateau (app. $72 \mathrm{~km}^{2}$ ) in the present-day topography and represent tangible war geoheritage. But much of these geoheritage was also lost in post-war periods, e.g. near the village of Vrtojba (SW Slovenia) where in 1917 over $12 \mathrm{~km}$ of World War I trenches existed, but a century later no traces of war are visible in the present-day topography. Almost two hundred World War I bomb craters also existed around the village that are also not existent in the topography any more. Many anthropogeomorphological traces of war are thus preserved only virtually and present intangible war geoheritage.
\end{abstract}

Keywords: pre-war landscape, post-war landscape, tangible war geoheritage, intangible war geoheritage, World War I, World War II, Slovenia

\section{Introduction}

Landscape is a complex combination of landforms and processes that is constantly changing [1]. "Unfortunately" some of these changes are also connected to war. Wars

\footnotetext{
^Corresponding Author: Mateja Breg Valjavec: Anton Melik Geographical Institute, Research Centre of the Slovenian Academy of Sciences and Arts, Novi trg 2, SI - 1000 Ljubljana, Slovenia, E-mail:

Matija Zorn, Daniela Ribeiro: Anton Melik Geographical Institute, Research Centre of the Slovenian Academy of Sciences and Arts, Novi trg 2, SI - 1000 Ljubljana, Slovenia
}

left many traces, thus we could speak about war landscapes (warscapes; [2, 3]). Some of these traces were created in the time of the war. These include defensive structures such as earthworks (embankments), primary and secondary traces of warfare itself (e.g. bomb craters and rubble mountains), conflict-related traces associated with military training and weapons testing facilities as well as, potentially, traces of conflict sustenance (e.g. conflictrelated mining and infrastructure) [4]. Some others were built later for public memory (e.g. monuments, ossuaries and cemeteries, museums) and are more a case of military landscapes [5].

World War I (WWI) or all previous wars have no living witnesses anymore, thus the physical landscape can be considered as a "last witness" of these conflicts [6, 7]. Physical landscapes of such areas consist of specific topography "war layers" that include anthropogeomorphic landforms being characteristic only for battlefields and supporting areas.

The study and mapping of anthropogeomorphological traces of war is per se a transdisciplinary endeavour as it combines elements of geomorphology and archaeology ("archaeogeomorphology"), but also military geography, peace and conflict studies [4: 11]. Such research can be done by using historical aerial photographs and 3D topography data. A huge amount of aerial photographs that exist for many war landscapes present a large, but "often overlooked source of information for archaeological, historical and landscape research" [8], and have a big potential for primary site discovery, documentation, and heritage management. "In many cases archival aerial photographs are the only source of data about cultural and natural phenomena” [9: 114].

A growing number of works demonstrate the value of aerial photography for the study of former battlefields (e.g. [6, 8, 10-14]), starting with WWI, when aerial photographs were used on a large scale for the first time. A comparison of different time series of aerial photographs gives an insight into the evolution of the landscape and presents a source for monitor the landscape dynamics [15].

In 21st century Europe war landscapes can be identified mostly by areas of WWI and World War II (WWII) 
battlefields as well as many conflict areas of civil wars. During the war, the battlefields as well as the hinterland were physically transformed thus leaving many anthropogeomorphological traces and in many cases also environmentally degraded landscapes [16]. The former present a potential war geoheritage that it is often seen as "dark" heritage [4], and can contribute to "dark tourism", which is a "rather emotive label" [17: 146] of tourism compared to a related and non-emotional "war tourism" concept [18].

The first step towards acknowledging this kind of heritage is to map all the existing war landscape elements. The mapping of geoheritage in Slovenia, specifically geomorphological features, has been done before (e.g. [19]), but this study is an attempt to map features that can be considered geoheritage and resulted from warfare.

The aim of this study is to present the application of historical aerial photographs of Slovenian territory, surveyed during both world wars and the post-war period, to (re)discover war geomorphological traces. Study sites highlight the potential of historical aerial photographs as well as photogrammetrically derived digital terrain models (DTMs) for the detection, mapping and quantification of war-related relief changes.

\section{Materials and Methods}

\subsection{Mapping geomorphological traces of war}

The recognition of geomorphological traces of war is based on analysing (i.e. comparing) historical aerial photographs and historical DTMs of war landscape (during war or close to war period) with present-day aerial photographs and DTMs. It consists of the:

(1) Extraction of visible war topography traces: War traces are recognized on historical and present-day topography data or only on the latter and can be proved by other historical sources.

(2) Extraction of virtual war topography traces: A nonexisting war traces in the present-day topography can be recognised from historical aerial photographs or historical DTMs.

\subsection{Study sites}

The ability to identify and to map war landscape and potential war geoheritage (e.g. trenches, craters, infrastructure) was tested at four study sites (war landscapes)
(Figure 1): the WWI Soča/Isonzo Front (A, B), the WWII German-Italian border (C) and the WWII German-Croatian border (D).

First two study sites (A and B) lie in the south-western part of Slovenia with a sub-Mediterranean climate. Temperatures in January are above $0^{\circ} \mathrm{C}$, and in July above $20^{\circ} \mathrm{C}$; precipitation is $1200-1700 \mathrm{~mm}$ [20]. Vrtojba village (A) with the population of app. 2500 lies in the flysch Vipava River valley at an elevation of app. $60 \mathrm{~m}$. Kras Plateau (B) is a karstic plateau at an elevation between 250 and $350 \mathrm{~m}$ at the study site. Several villages are located in the area, with the population up to several hundred people. Third study site (C) lies in the central part of the country in the Ljubljana Basin just north of the capital Ljubljana (population of app. 280.000) at an elevation of app. $300 \mathrm{~m}$. It has temperate climate with the temperature of the coldest month below $0{ }^{\circ} \mathrm{C}$, and of the warmest month above $15^{\circ} \mathrm{C}$; precipitation is $1000-1300$ $\mathrm{mm}$. The Ljubljana Basin is filled with fluvial-glacial deposits. The forth study site (D) lies in the eastern part of the county in the Sotla River valley at the edge of the Pannonia Basin; the bedrock is predominantly marl. It has a subPannonian (temperate) climate with similar temperatures as in the third study site; precipitation is $800-1000 \mathrm{~mm}$. Study site D lies just north of the settlement Nimno with the population of app. hundred people.

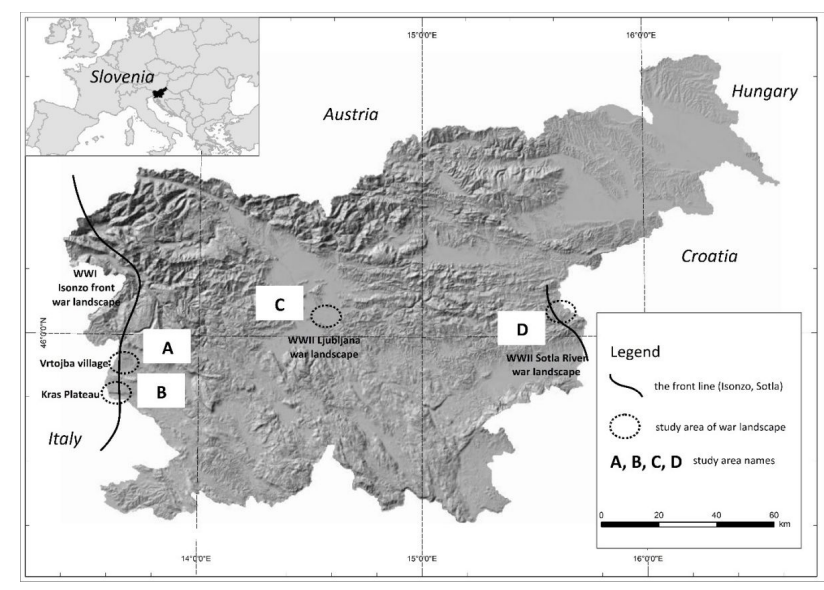

Figure 1: Study sites: Soča/Isonzo Front (A-Vrtojba, B-Kras Plateau) is an example of WWI war landscape, Ljubljana Plain (C) and Sotla River valley (D) are examples of WWII war landscapes.

\subsection{Aerial photographs}

Historical aerial photographs "are unique data sources for site discovery and mapping, for creating reliable archaeo- 
logical inventories and records of landscape change, supporting heritage management" [12: 232]. Thus, aerial photographs are recognised as a highly valuable source of information for (geo)heritage and environmental studies [9: 107, 114]. Their application has been made significantly easier by the development of geographic information systems [21], which - with suitably prepared data - allow a relatively easy comparison of different remote sensing data from various periods.

WWI aerial photographs of Slovenian territory were taken from Austro-Hungarian and Italian planes along the Soča/Isonzo Front. Gheyle et al. [15: 505] wrote for the Western Front that "historical aerial photographs cover the frontline area and the enemy hinterland up to $50 \mathrm{~km}$ behind the lines. ... Yet only rarely were WWI aerial photographs taken more than $100 \mathrm{~km}$ from the front."

In 1915 with the entry of Italy into WWI a six hundredkilometre long front was established between AustriaHungary and Italy including a ninety-kilometre section known as the Soča/Isonzo Front [22: 130] in present-day Slovenia. A very extensive collection of reconnaissance aerial photographs of the Soča/Isonzo Front that were taken by Austro-Hungarian planes is kept at the Vienna War Archives, and partly also at the Nova Gorica Regional Archives [23] and at the Bavarian Military Archive [12: 227]. These aerial photographs are mainly black-and-white nonmetric photographs that for most covered areas do not allow classical photogrammetric stereo processing, and hence they were in the past largely analysed only through visual interpretation (e.g. [24]).

The WWI aerial photographs of the Soča/Isonzo Front were recently visually analysed by several authors (e.g. [14, 23, 25-27]).

Contrary, the majority of WWII aerial photographs are metric and, with the application of digital photogrammetry [28], it was possible to obtain three-dimensional information (Figure 3).

The air forces (Royal Air Force or RAF, USAF and Luftwaffe) took photographs of all of Europe and partly also of North Africa and the Middle East. The majority of these aerial photographs are kept by three major international archives: two in the UK (The National Collection of Aerial Photography [29] in Edinburgh and the Imperial War $\mathrm{Mu}-$ seum in London; [30]) and one in the US (the National Archives and Records Administration; [31]).

Aerial photography collections that cover Slovenian territory were taken from May 1943 until December 1944 and result from 235 reconnaissance flights (Figure 2). During WWII, the German (Luftwaffe) and British (RAF) planes primarily took photographs of the area along the railway that ran across Slovenian territory and connected the port of Trieste with Austria, the interwar border area between Italy and Yugoslavia (the Rapallo border), and the Slovenian coast. This resulted in an extensive collection of historical aerial photographs of Slovenian territory that was, however, dispersed among various archives [32] (Figure 2).

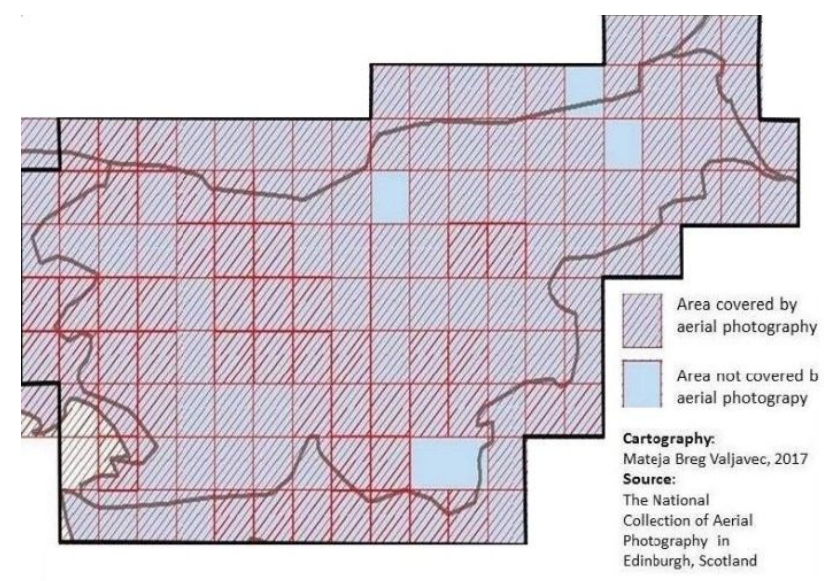

Figure 2: Coverage of Slovenian territory by the aerial surveys conducted from May 1943 to December 1944 from 235 reconnaissance flights, kept at the National Collection of Aerial Photography in Edinburg (Scotland); the grid resolution is $10 \times 10 \mathrm{arc}$ min.

After WWII up to 1972 aerial photographs of Slovenian territory were taken by the Military Geography Institute (VGI) in Belgrade, which carried out surveys primarily for defence purposes and partly also for major civil engineering projects (e.g. motorways). The collection of post-war aerial photographs includes mainly metric photographs that enable photogrammetric stereoimage-processing and generation of historical DTMs (Figure 7B). Post-WWII images are well preserved and largely accessible to the public from the Archives of Aerial Photos [33]. Part of the photographs taken before 1972 is still kept exclusively at the VGI in Belgrade [32].

Historical aerial photographs can present some technical issues, mainly related to their metrical accuracy, since the calibration data required for photogrammetry tends to be unavailable. This can limit the possibilities for integrating aerial photograph-based data with other digital datasets in which the accuracy of derived mapping is important [12]. Nevertheless, some technical solutions exist, especially with regard to non-metric photogrammetry that can be used $[34,35]$.

Before the use, historical aerial photographs need georeferencing (e.g. [36]). For this, we used ArcGIS. 


\subsection{Historical and present-day DTMs}

Conventional photogrammetric procedures use stereo photographs for 3D-spatial and topography reconstruction. This requires a stereo effect, which is created when two images sufficiently overlap one another (usually 60 to $80 \%)$ and the optical axes are not too convergent [33, 37, 38]. In contrast to the WWI reconnaissance photographs, a significant share of WWII images were already taken with a stereoscopic camera and enable photogrammetric stereoimage-processing (Figure 3).

Figure 3 shows digital photogrammetric processing of a WWII aerial photograph by using Erdas Imagine Leica Photogrammetry software. With this procedure, we created historical DTMs.

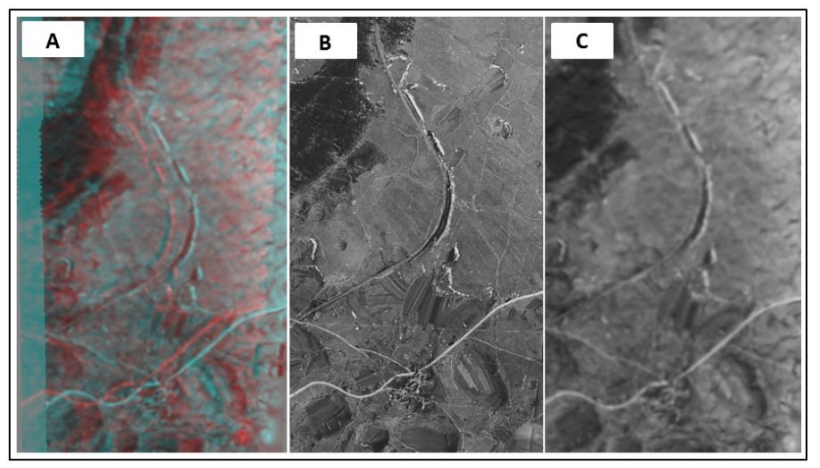

Figure 3: The figures show a digital photogrammetric processing of historical aerial photograph from WWII showing the area near Divača's WWII military airport (Kras Plateau, SW Slovenia). Stereoeffect $(A)$ is a three-dimensional image generated by a stereopair that is the basis for the generation of orthophoto (B) and DTM (C).

Between 2011 and 2015 airborne laser scanning of Slovenia took place and covered the entire country [39]. The laser scanning records enable the elaboration of very precise present-day DTMs (resolution of $1 \mathrm{~m}$ ) as the laser scanning density for the most of the country was 5 points $/ \mathrm{m}^{2}$. From these data, we elaborated present-day LiDAR DTMs for the study sites.

\section{Results}

\subsection{Geomorphological traces of war}

Geomorphological traces of war can be in general placed into two groups: (1) landforms that are the remains of war infrastructure (in all study sites), e.g. war trenches, machine gun nests, bunkers, road/railway embankments and cuts; (2) landforms that were formed by human-induced land degradation during battles, e.g. bomb craters (study site A).

Among the most preserved war geomorphological traces in studied areas are war trenches, in hard limestone or dolomite bedrock (study site B; Figure 4), while there are almost no such traces preserved in soft unconsolidated sediments of alluvial plains (study site $\mathrm{C}$ ) and flysch rock (study site A; Figure 6). In general, war trenches are (Figure 4A) concave elongated landforms up to several meters deep wide. Individual trenches can be up to few hundred meters long and connected with surrounding trenches forming a trench network. Some trenches are forming simple straight lines and some have a more complex form, e.g. a zigzag shape (Figure 4C). Machine gun nests and bunkers (Figure 4) are all concave landforms of more or less circular shape; therefore, they can also be misinterpreted as bomb craters, which are also circular. The mean perimeter (and area) of bomb crater in study site A is $24.5 \mathrm{~m}\left(46.5 \mathrm{~m}^{2}\right)$; the maximum being $45 \mathrm{~m} \mathrm{(133 \textrm {m } ^ { 2 } )}$ and the minimum $8 \mathrm{~m}\left(4 \mathrm{~m}^{2}\right)$. They are unregularly distributed around trenches, while bunkers and machine gun nests are mostly part of the trench network.

Railway embankments and cuts were made as a supporting transport infrastructure (study site C; Figure 7). Both elongated, the former convex and latter concave, are rarely preserved in original form. Often, the material of embankments was used as a construction material for postwar reconstructions or the area was change later for civil transport purposes. More detailed analysis of geomorphological traces is presented in following sub-sections, Figures 4-7 and summarised in Table 1.

\subsection{Preserved geomorphological traces of war}

Geomorphological traces of WWI in the study site B were visually recognized on LiDAR DTM. Over 111 kilometres of trenches or app. $1.5 \mathrm{~km} / \mathrm{km}^{2}$ (Table 1) are preserved in the topography of north-western part of Kras Plateau (SW Slovenia; Figure 4) in a study site that covers app. $72 \mathrm{~km}^{2}$ around the villages Lokvica, Opatje selo, Nova vas, Kostanjevica na Krasu, Sela na Krasu etc.

Figures 4D and 4E show the location of the study site and the spread of WWI trenches. Figure $4 \mathrm{C}$ shows perfectly preserved trench lines and Figure 4A shows a wider area of trenches around natural enclosed karst depressions (dolines). All these figures are using LiDAR shaded topography as a background, while Figure 4B uses con- 


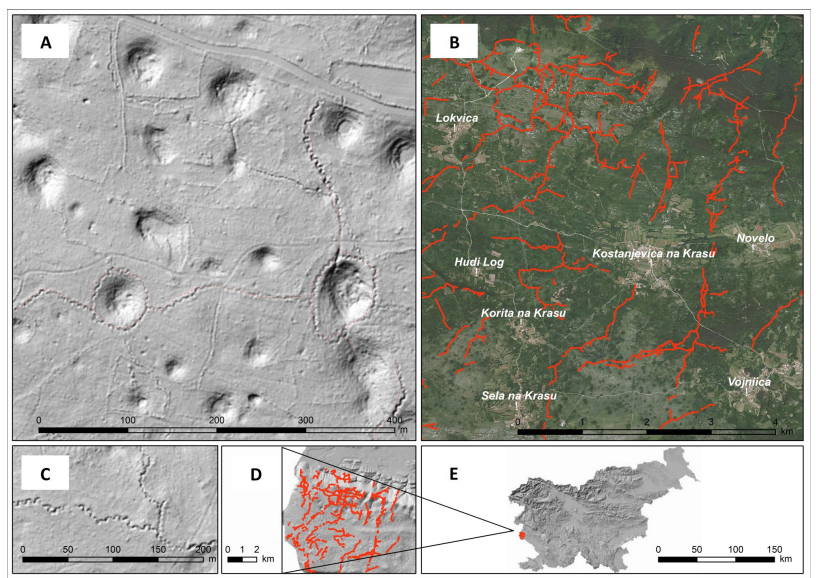

Figure 4: WWI war landscape of the Soča/Isonzo Front in the NW part of Kras Plateau (SW Slovenia) presented on shaded LiDAR DTM (1 m; A, C-E) and contemporary aerial photograph (2012; B; red lines present mapped trench lines).

temporary aerial photograph (2012) overlaid by mapped trench lines (red lines).

During the WWI, the Soča/Isonzo Front severely affected the cultural landscape of Kras Plateau [40]. In addition to the devastation caused by the bombing of the villages and the area around the front line, stones from dry walls (a typical feature in karstic cultural landscapes) were used for the construction of roads or their hardening [41, 42].

For WWI front lines were typical, meaning that traces of intense warfare are limited to strips some tens kilometre wide $[7: 58,43]$.

Although this "static warfare" was no longer in use during WWII, we can still find similar geomorphological traces. In the Sotla River valley (SE Slovenia) (study site D; Figure 5; Table 1) traces of trenches, bunkers and machine gun nests are preserved. These were not put in place because of the nearby front line, but are part of the German border fortification at the WWII border between Germany and the Independent State of Croatia.

\subsection{Non-preserved geomorphological traces of war}

Many geomorphological traces are preserved only "virtually" as a historical record and present intangible war geoheritage. By comparing present-day LiDAR DTM with available historical aerial photographs we noticed that there are many "lost" war landscapes.

Over $12 \mathrm{~km}$ of WWI trenches of the Soča/Isonzo Front were mapped around the village of Vrtojba (SW Slove-

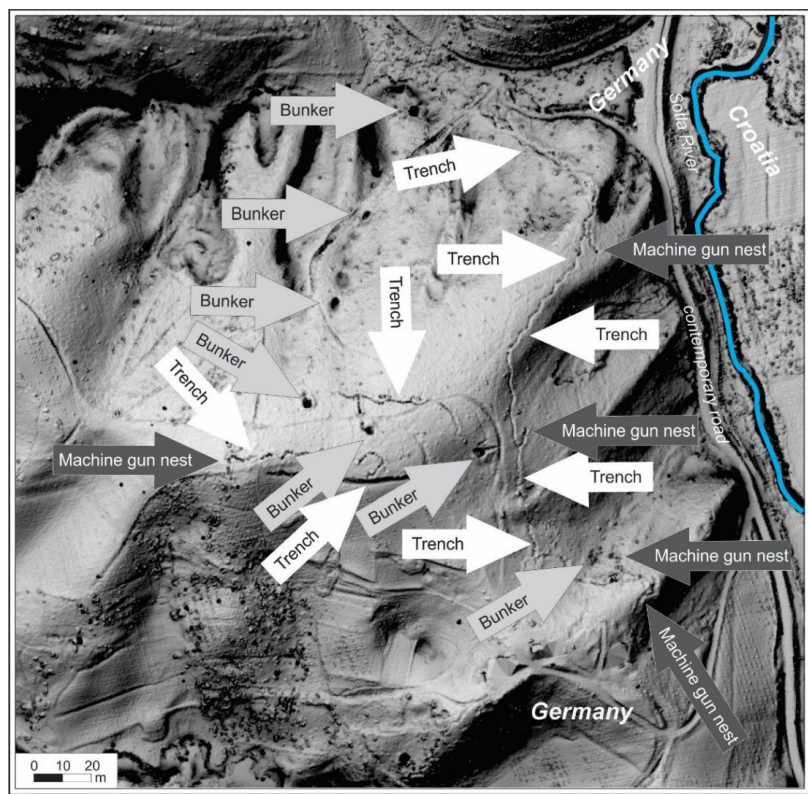

Figure 5: WWII war landscape in the Sotla River valley (SE Slovenia) as seen on the shaded LiDAR DTM (1 m) (For location see Figure 1).

nia; study site A) for the year 1917 (Figures 6A and 6C), but after a century no trenches can be recognized in the present-day LiDAR topography (6B). Over 187 bomb craters or over 155 per $\mathrm{km}^{2}$ (Table 1) were also mapped (Figures $6 \mathrm{~A}$ and $6 \mathrm{C}$ ), but almost none can be recognized today (Figures 6B and 6D). They have not been preserved due to the intensive land use. Similar results were also found in Belgium, where WWI traces of the Western front were "quickly restored" [7: 11]. Gheyle et al. [7] reported that just a few percent of trenches that were mapped from WWI aerial photographs were recognised in the present-day LiDAR DTM.

"Virtual" traces of war can be found also from WWII. On Figure 7A (study site C) a 1959 aerial photograph (scale 1:10,000) of an area near Ljubljana (central Slovenia) shows the route of a former WWII German railway. A 3D model (Figure 7B) elaborated through stereo evaluation of selected 1959 photographs shows that the railway ran along a cut (Figure 7B-left) and an embankment (Figure 7B-right). After the war the railway was dismantled and the embankment was removed, so on a present-day LiDAR DTM (Figure 7C) these man-made landforms can be barely identified (Table 1). However, on a 2011 aerial photograph (Figure 7D) the route of the former railway can be identified based on the land use (forest). 

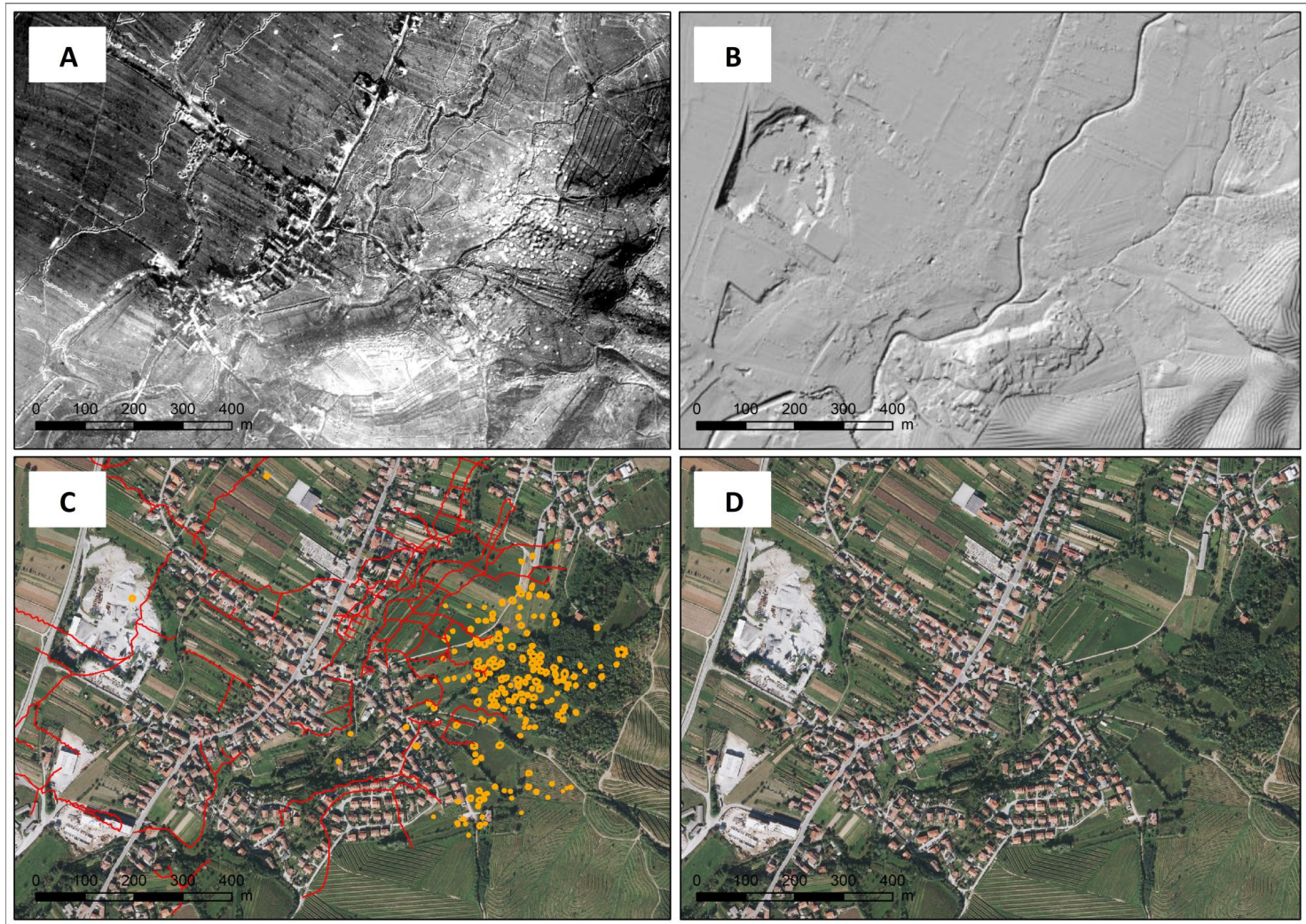

Figure 6: Landscape change in the village of Vrtojba (SW Slovenia): (A) an aerial photo from 1917 (scale 1:2,500), (D) a present-day orthophoto (2012; scale 1:5,000) (C) with WWI Soča/Isonzo Front trenches (red lines) and bomb craters (yellow dots) and (B) a present-day LiDAR DTM where no geomorphological traces of war can be recognized (For location see Figure 1).

Table 1: Recognised war geoheritage in study sites.

\begin{tabular}{|c|c|c|c|c|c|}
\hline $\begin{array}{l}\text { Study site } \\
\text { (time period) }\end{array}$ & $\begin{array}{l}\text { Area } \\
\left(\mathrm{km}^{2}\right)\end{array}$ & War geoheritage & $\begin{array}{l}\text { Length or } \\
\text { number }\end{array}$ & $\begin{array}{l}\text { War geoheritage/ } \\
\text { per km² }\end{array}$ & $\begin{array}{c}\text { Preserved in } \\
\text { present-day } \\
\text { landscape } \\
\end{array}$ \\
\hline$A(W W I)$ & app. 1.2 & $\begin{array}{l}\text { 1) trenches } \\
\text { 2) bomb craters }\end{array}$ & $\begin{array}{l}\text { 1) }>12 \mathrm{~km} \\
\text { 2) }>187\end{array}$ & $\begin{array}{l}\text { 1) app. } 10 \mathrm{~km} / \mathrm{km}^{2} \\
\text { 2) }>155 / \mathrm{km}^{2}\end{array}$ & No \\
\hline $\mathrm{B}(\mathrm{WWI})$ & app. 72 & trenches & $>110 \mathrm{~km}$ & app. $1.5 \mathrm{~km} / \mathrm{km}^{2}$ & Yes \\
\hline C (WWII) & $\begin{array}{l}\text { app. } \\
0.07\end{array}$ & $\begin{array}{l}\text { 1) trenches } \\
\text { 2) bunkers } \\
\text { 3) machine gun nests }\end{array}$ & $\begin{array}{l}\text { 1) app. } 0.5 \mathrm{~km} \\
\text { 2) } 7 \\
\text { 3) } 5\end{array}$ & $\begin{array}{l}\text { 1) app. } 7 \mathrm{~km} / \mathrm{km}^{2} \\
\text { 2) app. } 100 / \mathrm{km}^{2} \\
\text { 3) }>70 / \mathrm{km}^{2}\end{array}$ & Yes \\
\hline D (WWII) & app. 0.5 & $\begin{array}{l}\text { railway embankment } \\
\text { and cut }\end{array}$ & $1 \mathrm{~km}$ & app. $2 \mathrm{~km} / \mathrm{km}^{2}$ & Partly \\
\hline
\end{tabular}

\section{Discussion}

"The scale of landscape transformation over the last century, within Europe and globally, has been great. War, urban expansion, land use and land cover changes and construction projects, among other activities and processes, have heavily altered our landscape." This resulted in a great "loss of evidence from which to understand the past" [44: 7]. But this "evidence" can be rediscovered with the use of remote sensing.

Studying landscape changes with the use of remote sensing depends primarily on the availability of useful historical sources (in our case aerial photographs), their quality, state of preservation, and technological options for further processing. Nonetheless, historical aerial photographs although highly applicable may have some disadvantages that limit their use: 1) poor spatial resolution compared to some other remote sensing data (e.g. LiDAR); 


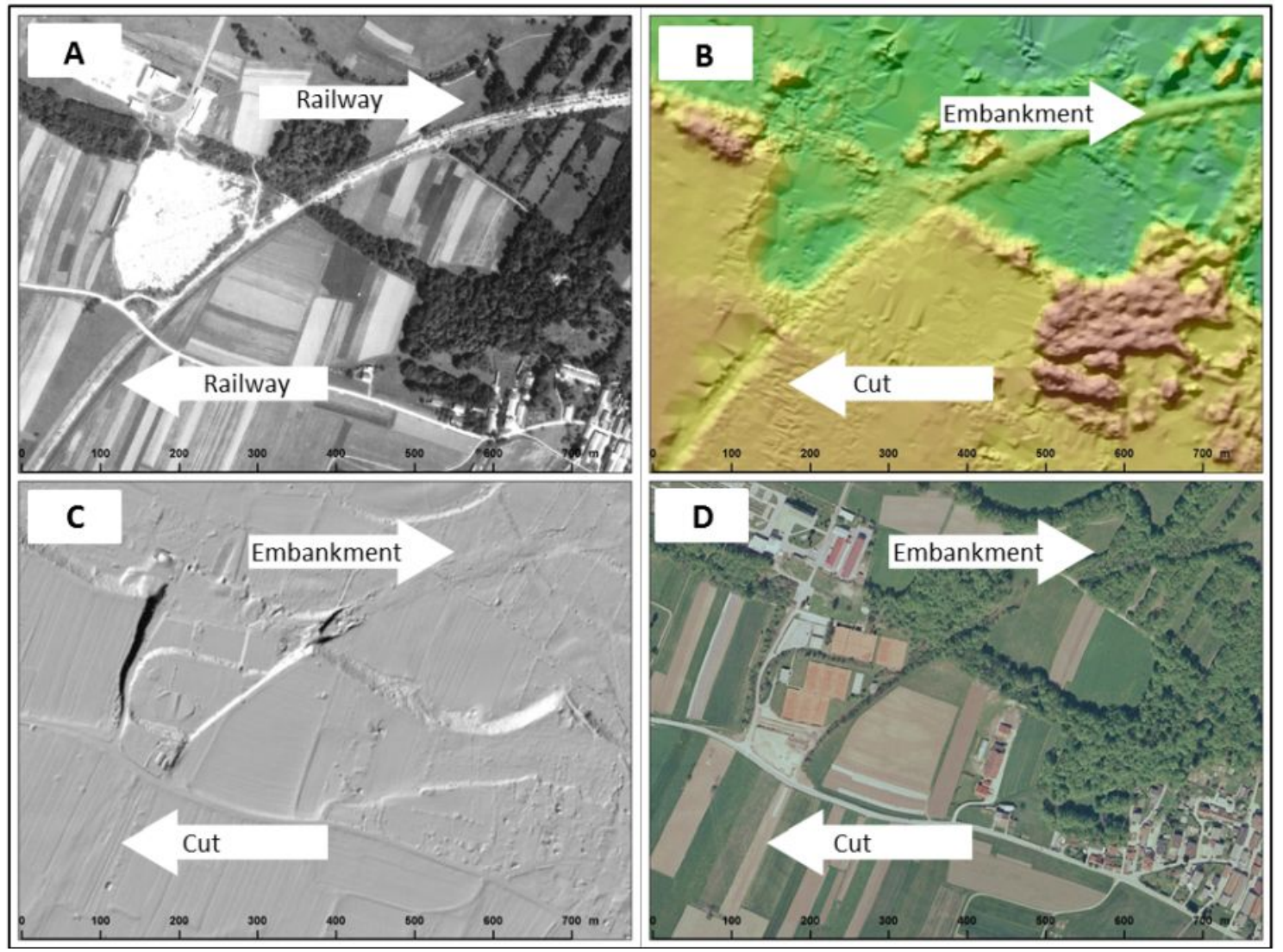

Figure 7: On (A) an aerial photograph from 1959 north from Ljubljana (central Slovenia) the course of the former WWII German railway is visible. On (B) a 3D 1959 landscape model (5×5 m resolution) made from stereoimaging, it can be seen that the railway ran along a cut (on the left) and an embankment (on the right). After the war the railway was dismantled and the embankment was removed, so that (C) on presentday LiDAR DTM these anthropogenic relief forms are almost non recognizable, while the course of the former railway can be recognized on (D) a 2011 aerial photograph based on the land use (For location see Figure 1).

2) lack of coordinates of fiducial marks and distortion parameters of lenses generate problems for georeferencing; 3) seasonal diversity in temperate and cold climates (especially in overgrown areas) when photographs are taken at various time of the year; 4) poor quality of negatives and prints, and 5) accessibility problems related to deficiencies in cataloguing or classified data [9]. Other "general" problems are: 1) different cameras used, complicating the identification of fiducial marks, which vary between cameras; 2) missing calibration certificates; 3) nonuniform heights of flight; 4) low radiometric quality, and 5) unsuitable weather conditions or non-optimal times of day for photography [45].

War also acts as an impulse for landscape change. By comparing pre-war and post-war landscapes (Figures 6 and 7) it is possible to track these changes. Good examples are "bombing landscapes", i.e. war landscapes that were altered by "bombturbation" [46]. On some WWI battlefields "over 50 million craters were produced across a several hundred hectare area in a matter of a few months" [43:
170]. In case of the village of Vrtojba (study site A; Figures 6 and 8) the surrounding flysch hills were traditionally terraced vineyards. Due to intensive bombing performed during WWI (over 155 per $\mathrm{km}^{2}$; Table 1) part of these terraces were abandoned and nowadays these areas are covered by forest (Figure 8). Abandonment of WWI war devastating areas are known also from elsewhere, e.g. in France, "the government deemed parts of the devastated front zone to be physically and environmentally too damaged for human habitation and impossible to clean up" [7:55]. In such areas land "returned" to nature (forest), thus surface war features are well preserved.

The WWI aerial photographs of Slovenia cover mostly small areas. They are largely non-metric, and hence are almost impossible for digital photogrammetric processing and 3D measurements. For this reason, they enable mainly analysis through visual interpretation. Due to its technical simplicity and its importance for military purposes, visual photointerpretation was already used during WWI [23]. For further processing of WWI photographs more advanced 


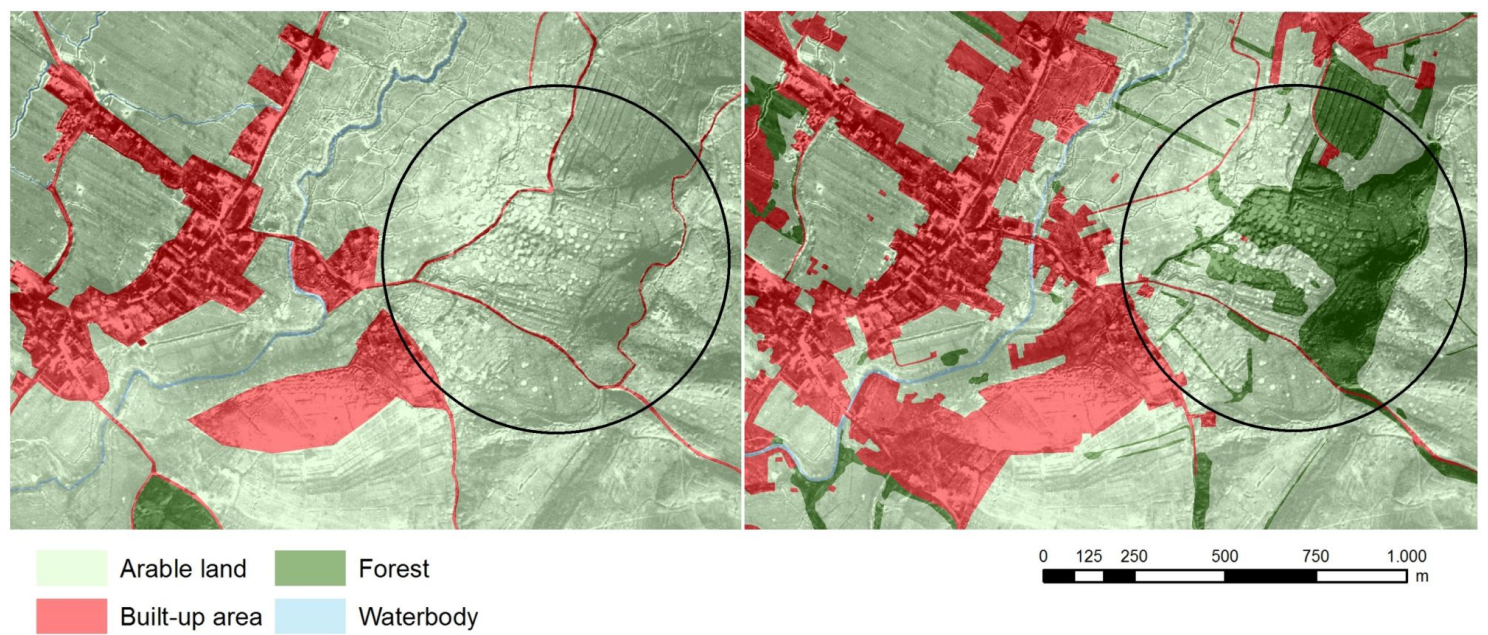

Figure 8: Land use changes in the village of Vrtojba (SW Slovenia). On the left we can see the land use in the time of the Second Habsburg Military Land Survey from the second half of the 19th Century, and on the right the current land use. The background image in both cases is from 1917.

software is needed (e.g. Agisoft) and more overlapping images are required for possible 3D analyses using digital photogrammetry [28].

The WWII photographs have better technical quality (fiducial marks and other image metric elements), which allows stereoimage processing and visual image interpretation of landscape topography. The post-WWII photographs are metrically even more advanced. They were primarily intended for the production of topographic maps and orthophotos for military or civilian purposes. Thus, they enable the elaboration of high-quality DTMs and the analysis of a wide range of natural and human-induced landscape changes.

The use of historical aerial photographs to determine war geoheritage (or any other heritage in the landscape) is limited to non-forested areas. With the help of LiDAR data, we can also map war landscapes, that are today under forest. "While most geomorphological traces of warfare have been obliterated in areas which have since been ploughed or built over, many such traces still exist in forested areas. Without the aid provided by historical documents such as legacy aerial photographs [or LiDAR data], the mapping of such features until recently required time-intensive field survey, an often prohibitive approach given the large spatial scale of modern warfare" [4:16]. Besides the under forest preserved WWI tranches on Kras Plateau (study site B), another such an example in Slovenia are also the postWWI fortifications and earthworks at interwar border between Italy and Yugoslavia [47].

The type of terrain is another issue related to the level of preservation of war geoheritage. Considering the presented study sites, geomorphological traces are less pre- served in soft rocks (flysch) (Vrtojba, study site A) and non-consolidated sediments (alluvium) (Ljubljana Plain, Figure 1-study site $\mathrm{C}$ ). While these traces are generally better preserved in hard rocks (limestone, dolomite) (Kras Plateau, Figure 1-study site B). This is connected with the possibility of intensive land use in non-karstic landscapes (study sites A and C) and limited land use possibilities in karstic landscapes (study site B) [48]. These can be also very site-dependent, as show the cases from the Western front with thicker regolith layer. This corroborates with examples from other countries, while on Verdun battlefield (France) the bombed landscape is well preserved [49] in Belgium many geomorphological traces of war were levelled after the war [7].

\section{Conclusion}

The application of modern photogrammetric techniques to historical aerial photographs, allows a detailed overview of war remains [50]. They provide unique records that cannot be matched by other spatial sources or maps. They especially hold value for those working in a landscape framework as they can be used to track landscape changes through the entire twentieth century [12]. As Pollard and Barton [51: 91] put it: "Place aerial photographs and panoramas together, and one has the most accurate multidimensional image of the landscape that it is possible to achieve." The application of digital terrain models (DTMs) in the investigation of war landscapes can addi- 
tionally add to the research of geomorphological traces of war [4].

We used aerial photographs and high resolution $\mathrm{Li}-$ DAR DTM to recognize war landscapes and war geoheritage. Upon results, we created the warscape topography layers from which war traces could be recognized.

As similar studies show (e.g. [7]), this kind of research, hold a lot of potential of finding, documenting, and ultimately acknowledging war geomorphological traces as geoheritage.

\section{References}

[1] Avanzini M., Carton A., Seppi R., Tomasoni R., Geomorphosites in Trentino: a first census. II Quaternario, 2005, 18(1), 63-78

[2] Nordstrom C., A different kind of war story. University of Pennsylvania Press, Philadelphia, 1997

[3] Korf B., War. In: Richardson D., Castree N., Goodchild M.F., Kobayashi A., Liu W., Marston R.A. (Eds.), The International Encyclopedia of Geography: People, the Earth, Environment, and Technology. Wiley, 2017, DOI: 10.1002/9781118786352

[4] Hesse R., Geomorphological traces of conflict in high-resolution elevation models. Applied Geography, 2014, 46, 11-20, DOI: 10.1016/j.apgeog.2013.10.004

[5] Šantrůčková M., Military landscapes as a cultural heritage. In: Klingorová K., Semian M. (Eds.), Military and Postmilitary Landscapes: Abstract Book. Historical Geography Research Centre, Praha, 2018, 13

[6] Stichelbaut B., Cowley B.D., Introduction: Conflict Landscapes and Archaeology from Above. In: Stichelbaut B., Cowley D. (Eds.), Conflict Landscapes and Archaeology from Above. Ashgate, Farnham, Surrey, 2016, 1-9

[7] Gheyle W.,Stichelbaut B., Saey T., Note N., Van den Berghe H., Van Eetvelde V., Van Meirvenne M., Bourgeois J., Scratching the surface of war. Airborne laser scans of the Great War conflict landscape in Flanders (Belgium). Applied Geography, 2018, 90, 55-68, DOI: 10.1016/j.apgeog.2017.11.011

[8] Stichelbaut B., Forgotten and Lost-Archival Research of Aerial Photographic Collections of the Western Front 1914-1918: A Guide to the Archives. Založba ZRC, Ljubljana, 2015

[9] Zapłata R., Różycki S., Historic aerial photographs in the analysis of cultural landscape - case studies from Poland. In: Ivanišević V., Veljanovski T., Cowley D., Kiarszys G., Bugarski I. (Eds.), Recovering Lost Landscapes. Institute of Archaeology, Belgrade, 2015,107-115

[10] Stichelbaut B., Bourgeois J., Saunders N., Chielens P. (Eds.), Images of Conflict: Military Aerial Photography and Archaeology. Cambridge Scholars Publishing, Newcastle upon Tyne, 2009

[11] Cowley D.C., Standring R.A., Abicht M.J., Landscapes through the Lens: an introduction. In: Cowley D.C., Standring R.A., Abicht M.J. (Eds.), Landscapes Through the Lens: Aerial Photographs and Historic Environment. Oakville, Oxford, 2010, 1-6

[12] Cowley D.C., Stichelbaut B.B., Historic aerial photographic archives for European archaeology. European Journal of Archaeology, 2012, 15(2), 217-236, DOI: $10.1179 / 1461957112$ Y.0000000010
[13] Stichelbaut B., Chielens P., The Great War Seen from the Air: In Flanders Fields, 1914-1918. Mercatorfonds, Brussels, 2013

[14] Cuttini R., Scroccar M., Ali sulla storia = Na krilih zgodovine = Wings on History. Comune di Monfalcone, Monfalcone, 2014

[15] Gheyle W., Dossche R., Bourgeois J., Stichelbaut B., Van Eetvelde V., Integrating archaeology and landscape analysis for the cultural heritage management of a World War I militarised landscape: the German field defences in Antwerp. Landscape Research, 2014, 39(5), 502-522, DOI: 10.1080/01426397.2012.754854

[16] Hupy J.P., The environmental footprint of war. Environment and History, 2008, 14(3), 405-421, DOI: 10.3197/096734008X333581

[17] Stone P.R., A dark tourism spectrum: Towards a typology of death and macabre related tourist sites, attractions and exhibitions. Tourism, 2006, 54(2), 145-160

[18] Tizzoni E., The touristification of Great War heritage in the province of Trento between European history and local identity. AlmaTourism, 2016, 7(5), 84-104, DOI: 10.6092/issn.2036$5195 / 6170$

[19] Erhartič B., Conserving geoheritage in Slovenia through geomorphosite mapping. Géovisions, 2010, 35, 47-63

[20] Ogrin D., Podnebni tipi v Sloveniji (The climate types in Slovenia). Geografski vestnik, 1996, 68, 39-56

[21] Gregory I.N., Healey R.G., Historical GIS: structuring, mapping and analysing geographies of the past. Progress in Human Geography, 2007, 31(5), 638-653, DOI: 10.1177/0309132507081495

[22] Mlekuž D., Košir U., Črešnar M., Landscapes of death and suffering: archaeology of conflict landscapes of the Upper Soča Valley, Slovenia. In: Stichelbaut B., Cowley D. (Eds.), Conflict Landscapes and Archaeology from Above. Ashgate, Farnham, Surrey, 2016, 127-145

[23] Ravbar M., Avstro-Ogrsko letalstvo na soški fronti 1915-1917: Cesarska in kraljeva letališka infrastruktura v zaledju soške fronte. M.A. Thesis, Faculty of Arts, Ljubljana, 2011

[24] Technisches Handbuch für das Lichbildwesen. Komando der k.u.k. Luftfahrtruppen, Wien, 1918

[25] Soré P., L'aviazione nel Nord-Est: storia dei campi di volo del Friuli Venezia Giulia 1910-2010. Presscolor, Milano, 2010

[26] Ravbar M., Letališča na soški fronti (Airfields at the Soča front). Prispevki za novejšo zgodovino, 2012, 52(2), 231-256

[27] Cuttini R., Italian World War I aerial photographs for landscape study and public engagement. In: Stichelbaut B., Cowley D. (Eds.), Conflict Landscapes and Archaeology from Above. Ashgate, Farnham, Surrey, 2016, 265-227

[28] Linder W., Digital Photogrammetry: A Practical Course. Springer, Berlin, 2009

[29] National Archives and Records Administration https://www. archives.gov/

[30] Stichelbaut B., Gheyle W., Bourgeois J., Great War aerial photographs: the Imperial War Museum's Box Collection. In: Cowley D.C., Standring R.A., Abicht M.J. (Eds.), Landscapes Through the Lens: Aerial Photographs and Historic Environment. Oakville, Oxford, 2010, 235-246

[31] National Collection of Aerial Photography http://ncap.org.uk/

[32] Breg Valjavec M., Ribeiro D., Uporabnost zgodovinskih aeroposnetkov pri preučevanju pokrajinskih sprememb na ozemlju Slovenije (Applicability of historical aerial photographs in landscape change studies in Slovenia). In: Ciglič R., Perko D., Zorn M. (Eds.), Digitalni prostor, GIS v Sloveniji 12. Založba ZRC, Ljub- 
ljana, 2014, 71-84

[33] Historic Aerial Photographs http://www.gis.si/en/storitve/ historicni-aeroposnetki

[34] Triglav M., Kosmatin Fras M., Gvozdanovič T., Monitoring of glacier surfaces with photogrammetry, a case study of the Triglav glacier. Geografski zbornik, 2000, 40, 7-30

[35] Triglav Čekada M., Radovan D., Gabrovec M., Kosmatin Fras M., Acquisition of the 3D boundary of the Triglav glacier from archived non-metric panoramic images. Photogrammetrical Record, 2011, 26(133), 111-129, DOI: 10.1111/j.14779730.2011.00622.x

[36] Massasati A.S., Georeferencing aerial photography: beginners approach. Journal of Surveying Engineering, 2002, 128 (4), DOI: 10.1061/(ASCE)0733-9453(2002)128:4(159)

[37] Kraus K., Photogrammetry: Geometry from Images and Laser Scans. De Gruyter, Berlin, New York, 2007

[38] Cantoro G., Aerial photogrammetry: when archaeology meets SIFT. In: Ivanišević V., Veljanovski T., Cowley D., Kiarszys G., Bugarski I. (Eds.), Recovering Lost Landscapes. Institute of Archaeology, Belgrade, 2015, 117-128

[39] Triglav Čekada M., Bric V., Končan je projekt laserskega skeniranja Slovenije (The project of laser scanning of Slovenia is completed). Geodetski vestnik, 2015, 59(3), 586-592

[40] Nice B., La casa rurale nella Venezia Giulia. Nicola Zanichelli editore, Bologna, 1940

[41] Gams I., Lovrenčak F., Ingolič B., Krajna vas: a study of the natural conditions and of agrarian land utilization on the Karst. Geografski zbornik, 1971, 12, 221-261

[42] Panjek A., Kulturna krajina in okolje Krasa: 0 rabi naravnih virov v novem veku (Cultural Landscape and Environment of the Kras Plateau: On the Use of Natural Resources in the Modern Era). Založba Univerze na Primorskem, Koper, 2015

[43] Hupy J.P., Koehler T., Modern warfare as a significant form of zoogeomorphic disturbance upon the landscape. Geomorphology, 2012, 157-158, 169-182, DOI: 10.1016/j.geomorph.2011.05.024
[44] Ivanišević V., Veljanovski T., Cowley D., Kiarszys G., Bugarski I., Recovering lost landscapes - introduction to an aerial perspective. In: Ivanišević V., Veljanovski T., Cowley D., Kiarszys G., Bugarski I. (Eds.), Recovering Lost Landscapes. Institute of Archaeology, Belgrade, 2015, 7-10

[45] Lobato C.C., Historical aerial photographs to recover a lost landscape using digital photogrammetry: a case study of the Iron Age site of Cerro de la Mesa (Alcolea de Tajo, Toledo, central Spain). In: Ivanišević V., Veljanovski T., Cowley D., Kiarszys G., Bugarski I. (Eds.), Recovering Lost Landscapes. Institute of Archaeology, Belgrade, 2015, 117-128

[46] Hupy J.P., Schaetzel R.J., Introducing "bombturbation," a singular type of soil disturbance and mixing. Soil Science, 2006, 171(11), 823-836, DOI: 10.1097/01.ss.0000228053.08087.19

[47] Mikša P., Zorn M., Rapalska meja: četrt stoletja obstoja in stoletje dediščine (The Rapallo border: a quarter century of existence and a century of heritage). In: Ajlec K., Balkovec B., Repe B. (Eds.), Nečakov zbornik: procesi, teme in dogodki iz 19. in 20. stoletja. Znanstvena založba Filozofske fakultete, Ljubljana, 2018, 605-641

[48] Ciglič R., Hrvatin M., Komac B., Perko D., Karst as a criterion for defining areas less suitable for agriculture. Acta geographica Slovenica, 2012, 52(1), 61-98, DOI: 10.3986/AGS52103

[49] Hupy J.P., Schaetzel R.J., Soil development on the WWI battlefield of Verdun, France. Geoderma, 2008, 145(1-2), 37-49, DOI: 10.1016/j.geoderma.2008.01.024

[50] Stichelbaut B., The application of First World War aerial photography to archaeology: the Belgian images. Antiquity, 2006, 80, 161-172, DOI: 10.1017/S0003598X00093339

[51] Pollard T., Barton P., The use of First World War aerial photographs by archaeologists: A case study from Fromelles, Northern France. In: Hanson W.S., Oltean I.A. (Eds.), Archaeology from Historical Aerial and Satellite Archives. Springer, New York, 2013, 87-103 